\title{
B chromosome and NORs polymorphism in Callichthys callichthys (Linnaeus, 1758) (Siluriformes: Callichthyidae) from upper Paraná River, Brazil
}

\author{
Jocicléia Thums Konerat ${ }^{1}$, Vanessa Bueno ${ }^{1}$, Lucas Baumgartner ${ }^{2}$, \\ Isabel Cristina Martins-Santos ${ }^{2}$ and Vladimir Pavan Margarido ${ }^{1}$
}

B chromosomes are extra chromosomes from the normal chromosomal set, found in different organisms, highlighting their presence on the group of fishes. Callichthys callichthys from the upper Paraná River has a diploid number of 56 chromosomes $(26 m-s m+30 s t-a)$ for both sexes, with the presence of a sporadically acrocentric B chromosome. Moreover, one individual presented a diploid number of 57 chromosomes, with the presence of a morphologically ill-defined acrocentric B chromosome in all analyzed cells. The physical mapping of $5 \mathrm{~S}$ and $18 \mathrm{~S}$ rDNA shows multiple $5 \mathrm{~S}$ rDNA sites and only one pair of chromosomes with $18 \mathrm{~S}$ sites in C. callichthys, except for two individuals. These two individuals presented a third chromosome bearing NORs (Ag-staining and 18S rDNA) where 5S and 18S rDNA genes are syntenic, differing only in position. The dispersion of the $18 \mathrm{~S}$ rDNA genes from the main $s t-a$ chromosome pair 25 to one of the chromosomes from the $m$-sm pair 4 would have originated two variant individuals, one of which with the ill-defined acrocentric B chromosome. Mechanisms to justify the suggested hypothesis about this B chromosome origin are discussed in the present study.

Cromossomos B são cromossomos extras ao conjunto cromossômico normal, encontrado em diferentes organismos, com destaque para sua presença no grupo de peixes. Callichthys callichthys do alto rio Paraná tem um número diploide de 56 cromossomos $(26 m-s m+30 s t-a)$ para ambos os sexos, com a presença esporádica de um cromossomo B acrocêntrico. Além do mais, um indivíduo apresentou número diploide de 57 cromossomos, com a presença de um cromossomo B acrocêntrico morfologicamente mal definido em todas as células analisadas. O mapeamento físico do DNAr $5 \mathrm{~S}$ e $18 \mathrm{~S}$ mostrou múltiplos sítios de DNAr $5 \mathrm{~S}$ e apenas um par de cromossomos com sítio para o DNAr $18 \mathrm{~S}$ em C. callichthys, com exceção para dois indivíduos. Estes dois indivíduos apresentaram um terceiro cromossomo portador das RONs (Ag-RONs e 18S rDNA), onde os genes DNAr 5S e 18S são sintênicos, diferindo apenas na posição. A dispersão dos genes DNAr 18S do par de cromossomos principal st-a 25 para um dos cromossomos do par $m$-sm 4 teria originado dois indivíduos variantes, um dos quais com cromossomo B acrocêntrico mal definido. Mecanismos para justificar a hipótese sugerida sobre a origem deste cromossomo B são discutidos no presente estudo.

Key words: $18 \mathrm{~S}$ rDNA, 5S rDNA, Chromosomal rearrangements, FISH, Supernumerary chromosome.

\section{Introduction}

B chromosomes are extra chromosomes from the normal chromosomal set that follow their own evolutionary pathway (Camacho et al., 2000). Many studies concerning B chromosomes seek to clarify the molecular organization, ways of transmission (Camacho et al., 2000; Jesus et al., 2003; Jones \& Houben, 2003), origin and evolution of these chromosomes (Camacho et al., 2000; Mestriner et al., 2000; Jesus et al., 2003; Poletto et al., 2010); however it is not always possible to precisely determine their origin (Jamilena et al., 1994; Camacho et al., 2000).

In their differentiation process, B chromosomes would develop biologically meaningful but not essential functions (Mião et al., 1991; Plowman \& Bougourd, 1994), being considered selfish chromosomes, genomic parasites or accessories (Jones \& Houben, 2003; Poletto et al., 2010). Some authors suggest a correlation between their presence and environmental factors (Néo et al., 2000), or the possibility that these chromosomes convert into a reservoir of genetic

\footnotetext{
${ }^{1}$ Centro de Ciências Biológicas e da Saúde, Universidade Estadual do Oeste do Paraná. Rua Universitária 2069, 85814-110 Cascavel, PR, Brazil. vladimir.margarido@unioeste.br

${ }^{2}$ Departamento de Biologia Celular e Genética, Universidade Estadual de Maringá. Avenida Colombo, 5790, 87020-900 Maringá, PR, Brazil.
} 
variability, showing an evolutionary role (Rejón et al., 1987).

These additional chromosomes were found in different organisms, like in insects (Amos \& Dover, 1981), plants (Jones \& Houben, 2003), fungi (Mião et al., 1991), amphibians (Sharbel et al., 1998; Green, 2004), birds (Pigozzi \& Solari, 1998) and fishes. In fishes, they have been already described in Characiformes (Mizoguchi \& Martins-Santos, 1997; Voltolin et al., 2010), Labriformes (cited as Perciformes, Roncatti et al., 2007; Poletto et al., 2010), Siluriformes (Oliveira et al., 1993; ShimabukuroDias et al., 2005; Blanco et al., 2012), Gymnotiformes (Mendes et al., 2012) and Tetraodontiformes (Alves et al., 2008).
Cytogenetic studies in the Callichthyinae subfamily show the presence of B chromosomes only in Callichthys Linnaeus, 1758. These extra chromosomes were observed in different populations of $C$. callichthys, varying in size, quantity and morphology (Oliveira et al., 1993; Shimabukuro-Dias et al., 2005). In the present study, chromosomal structure of one population of $C$. callichthys was studied focusing the distribution of ribosomal sites and the biology of supernumerary chromosomes in this species, highlighting the occurrence of a morphologically ill-defined B chromosome and a hypothesis about its origin.

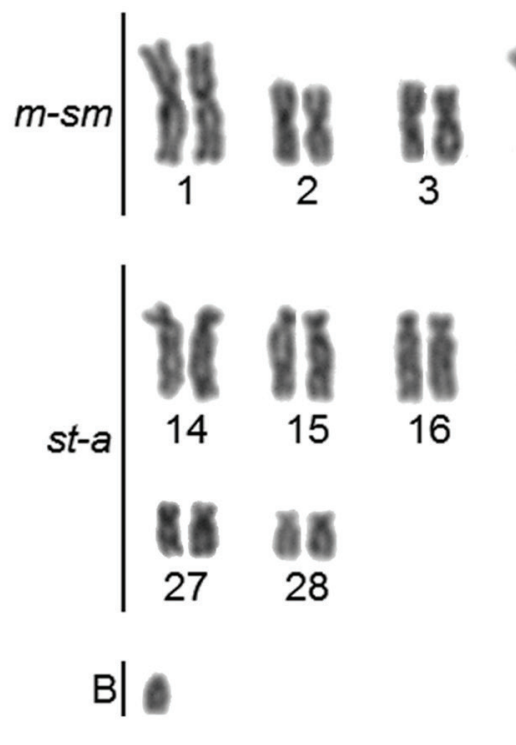

a

a

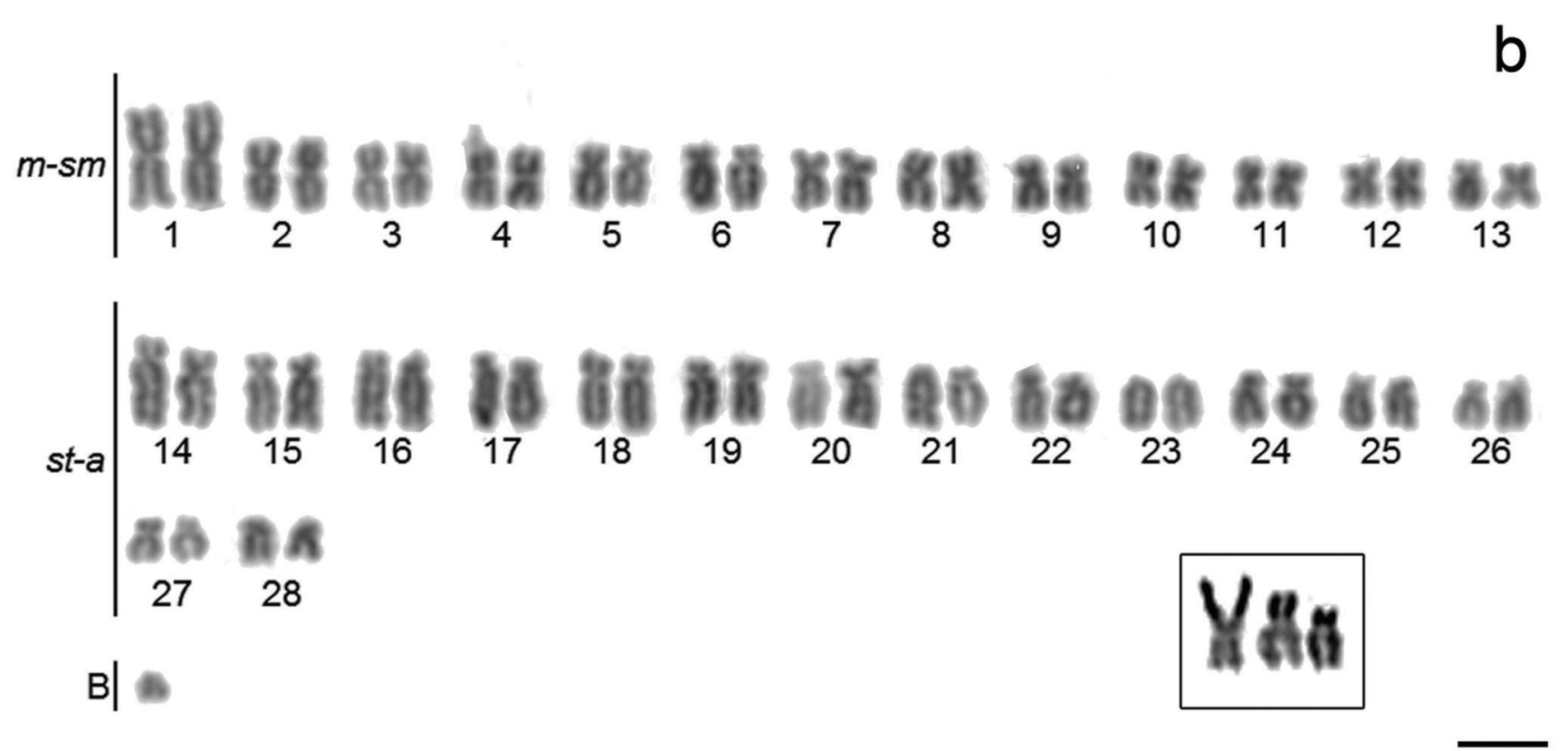

Fig. 1. Callichthys callichthys karyotypes stained by Giemsa: (a) with an acrocentric B chromosome and the third NORs bearing chromosome (interstitial) and (b) with the ill-defined acrocentric B chromosome and the third NORs bearing chromosome (terminal). The bar represents $5 \mu \mathrm{m}$. 


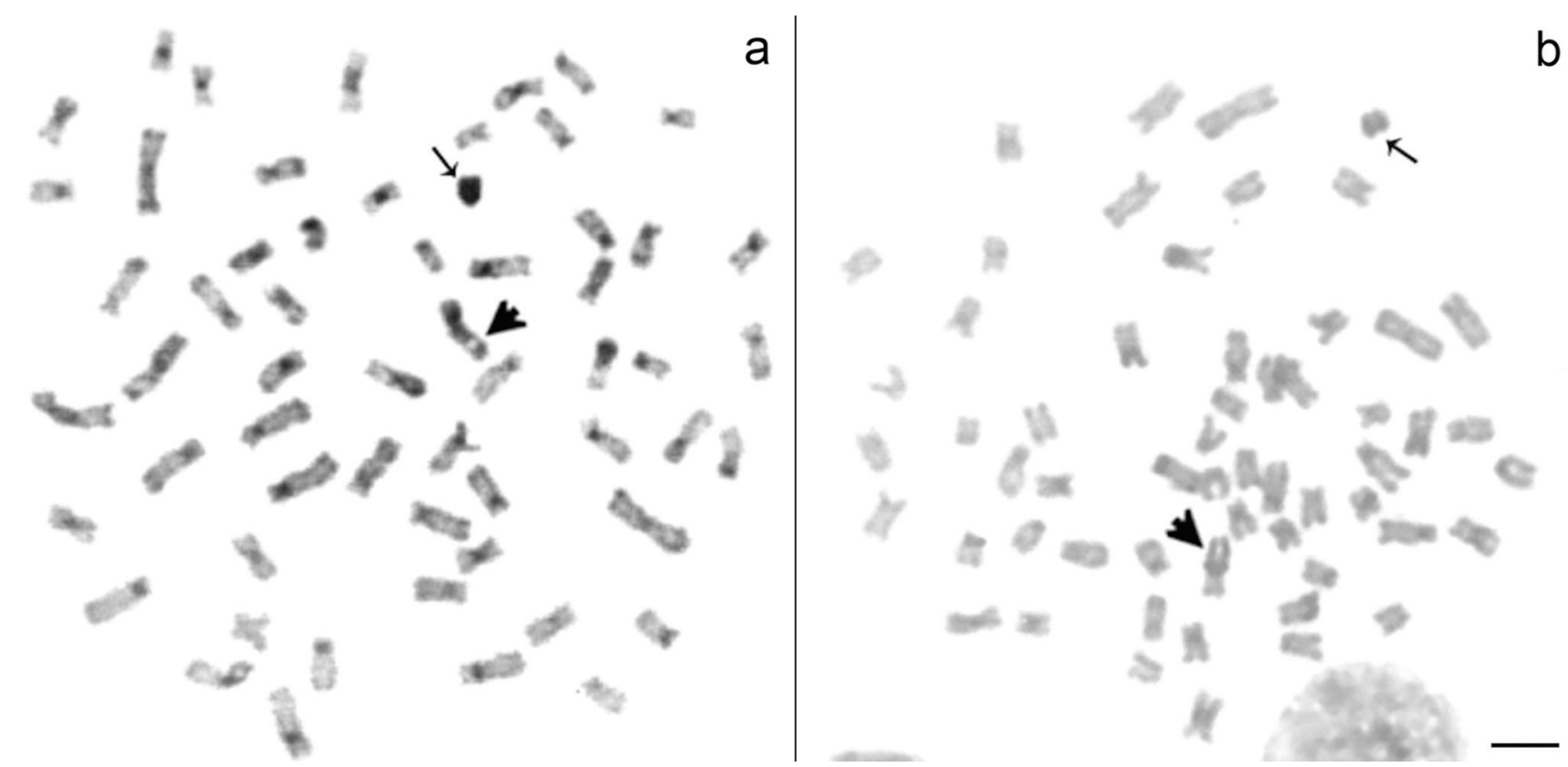

Fig. 2. C-banded metaphases of Callichthys callichthys: the arrowhead indicates the third NORs bearing chromosome and the arrow indicates the (a) acrocentric B chromosome and the (b) ill-defined acrocentric B chromosome. The bar represents $5 \mu \mathrm{m}$.

\section{Material and Methods}

Cytogenetic studies were carried out on Callichthys callichthys (6 males and 1 female) sampled from the Paraná River (Guaíra, Paraná State, Brazil). Voucher specimens were deposited in the Coleção Ictiológica do Núcleo em Pesquisas em Limnologia, Ictiologia e Aquicultura, Universidade Estadual de Maringá (NUP 6095 - C. callichthys). Metaphasic cells were obtained from the kidney (Bertollo et al., 1978; Foresti et al., 1993). Fish were anesthetized and sacrificed with clove oil according to Griffiths (2000). Heterochromatin was revealed through C banding (Sumner, 1972) and nucleolar organizer regions (NORs) were revealed through silver nitrate impregnation (Howel \& Black, 1980). Staining with the specific base fluorochromes Chromomycin $\mathrm{A}_{3}\left(\mathrm{CMA}_{3}\right)$ and 4',6-diamidino-2-phenylindole (DAPI) was performed following the procedure described by Schweizer (1980). Chromosomes types were classified in metacentric $(m)$, submetacentric $(\mathrm{sm})$, subtelocentric $(s t)$ or acrocentric $(a)$ based on the arm relationship criteria proposed by Levan et al. (1964).

The localization of the $5 \mathrm{~S}$ and $18 \mathrm{~S}$ rDNA sites in the chromosomes was performed using the fluorescence in situ hybridization (FISH) method (Pinkel et al., 1986 with modifications, Margarido \& Moreira-Filho, 2008), with probes obtained from the fish species Leporinus elongatus (Martins \& Galetti Jr.,1999) and Prochilodus argenteus (Hatanaka \& Galetti Jr., 2004), respectively. The probes were labelled through nick translation, with digoxigenin-11-dUTP (5S rDNA) and biotin-16-dUTP (18S rDNA) (Roche). Detection and amplification of the hybridization signal were made using
avidin-FITC and anti-avidin biotin (Sigma) for probes labelled with biotin, and anti-digoxigenin rhodamine (Roche) for probes labelled with digoxigenin. Slides were counterstained with DAPI $(50 \mu \mathrm{g} / \mathrm{mL})$ and analyzed in epifluorescence microscope (Olympus BX61). The images were captured using the software DP controller (Media Cybernetics).

\section{Results}

The analysis of mitotic cells revealed a diploid number of 56 chromosomes $(26 m-s m+30 s t-a)$ for both sexes, with the sporadic occurrence of an acrocentric B chromosome, which appears in three males e one female individuals (from $2.3 \%$ to $7.14 \%$ of metaphasic cells frequencies; 100 metaphase plates/ individual analyzed) (Fig. 1a). Also, one male individual had a B chromosome, like a morphologically ill-defined acrocentric one, present in all analyzed metaphases (Fig. 1b).

C-banding revealed centromeric heterochromatin, with pericentromeric and telomeric markings on some chromosomes and coincident markings with the intercalary region of the ribosomal sites in all specimens analyzed. Also, both the B chromosomes were completely heterochromatic (Figs. 2a, b). The intercalary region of the NORs was positive for $\mathrm{CMA}_{3}$ and negative for DAPI (Figs. 3a, b, c, d); indicating that the intercalary region of the $45 \mathrm{~S}$ rDNA has a $\mathrm{GC}$ rich composition. The ill-defined acrocentric B chromosome was not differentially stained by base-specific fluorochromes (Fig. 3c).

The NORs (Ag-staining and 18S rDNA) were simple, on the short arm of the chromosome pair 25 , although two individuals presented an extra marking, located on the short arm of one of 
chromosome from the $m$-sm pair 4 . This additional marking was interstitial in one individual and terminal on the other (Figs. 1a, b, box and Fig. 4b, c). The individual with the third NOR on terminal position had the ill-defined acrocentric B chromosome.

The physical mapping of ribosomal genes through FISH showed 5S rDNA sites on four $m$-s $m$ chromosome pairs. However, two individuals showed differences in the number of rDNA sites, one with seven and another with nine chromosomes bearing $5 \mathrm{~S}$ rDNA. Both individuals also had a third chromosome bearing $18 \mathrm{~S}$ rDNA. Three conditions were observed for the chromosomal pair 4: standard, 5S rDNA in the terminal position of the short arm of both chromosomes (Fig. 4a); variant $1,5 \mathrm{~S}$ rDNA in the terminal position of the short arm, syntenic to interstitial $18 \mathrm{~S}$ rDNA in only one homologous of the pair (Fig. 4b); variant 2, 5S rDNA in the interstitial position of the short arm syntenic to $18 \mathrm{~S}$ rDNA in terminal position on only one chromosome, with the occurrence of the ill-defined acrocentric B chromosome (Fig. 4c).

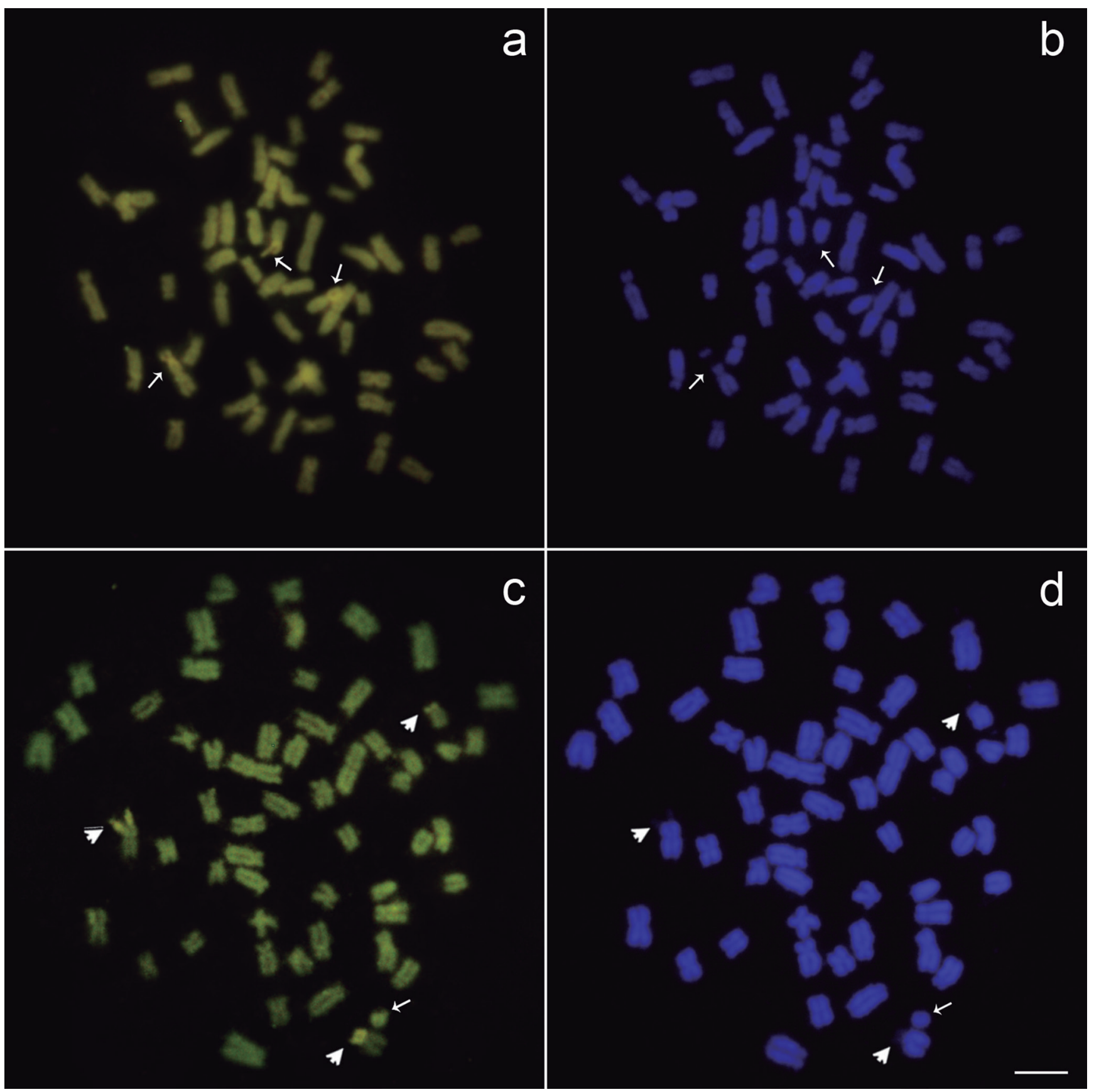

Fig. 3. Callichthys callichthys metaphases spreads with the third NOR bearing chromosome. The arrowheads indicate the NORs, marked in the interstitial position stained by (a) $\mathrm{CMA}_{3}$ and confirmed by (b) DAPI; and in terminal position stained by (c) $\mathrm{CMA}_{3}$ and confirmed by (d) DAPI. The bar represents $5 \mu \mathrm{m}$. 

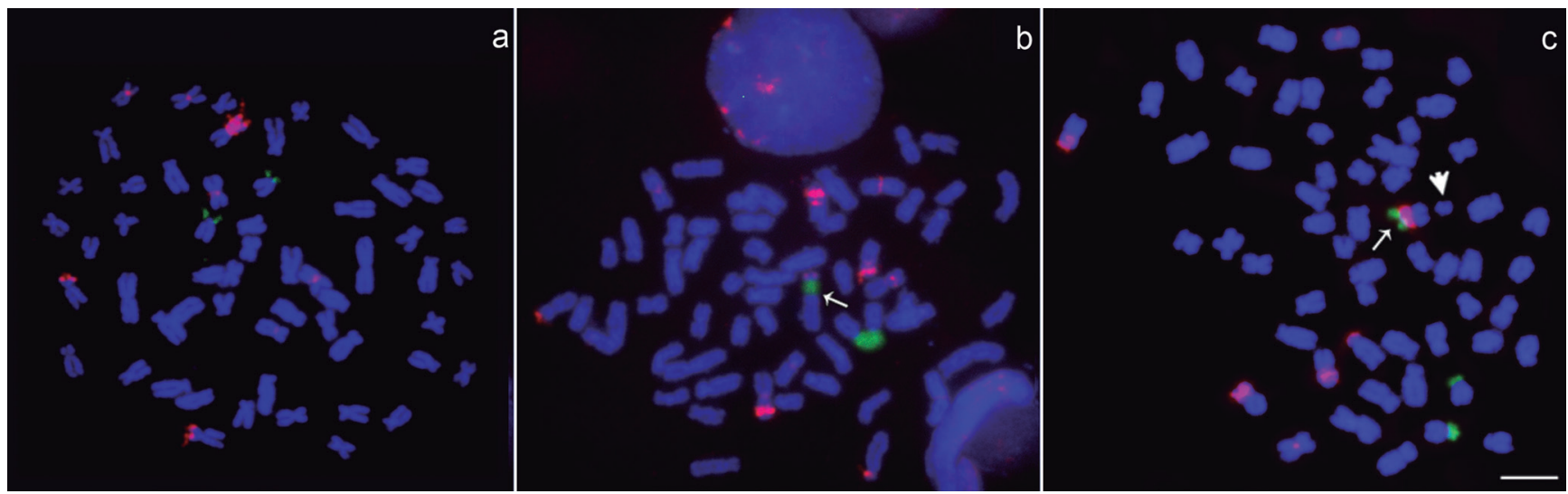

Fig. 4. Double FISH metaphases spreads of Callichthys callichthys with 5S (red) and 18S (green) rDNA probes. Standard metaphase (a) with 56 chromosomes and only the pair 25 bearing NORs. The arrows indicate the $m$-sm chromosome 4 with (b) $18 \mathrm{~S}$ rDNA in interstitial position and terminal 5S rDNA and (c) 18S rDNA in terminal position. The arrowhead shows the ill-defined acrocentric B chromosome. The bar represents $5 \mu \mathrm{m}$.

\section{Discussion}

B chromosomes have been described for approximately $5 \%$ of all Neotropical fishes (Oliveira et al., 2009) showing predominance in some groups. Callichthyidae has 199 species (Froese \& Pauly, 2013), with B chromosomes described for Corydoras (Oliveira et al., 1988) and Callichthys (Oliveira et al., 1993; Sanchez \& Fenocchio, 1996; Shimabukuro-Dias et al., 2005), varying in number, size and morphology.

A hypothesis was raised about the origin of the third NOR bearing chromosome and the $\mathrm{B}$ chromosome. The process would have begun with the amplification of the ribosomal genes on the main acrocentric chromosomes pair (25). It is possible that an event of dispersion to a third chromosome happened, as proposed by Schweizer and Loidl (1987), with the transposition of terminal segments from acrocentric chromosomes to nonhomologous, followed by homogenization. This dispersion carried terminal 5S rDNA to chromosome 4 ( $m$-sm), originating the variant 1 , with $5 \mathrm{~S}$ rDNA in the terminal position of the short arm, syntenic to interstitial $18 \mathrm{~S}$ rDNA in only one chromosome from the pair (Fig. 4b). Possibly, a paracentric inversion happened afterwards, originating variant 2 , with $5 \mathrm{~S}$ rDNA in the interstitial position of the short arm, syntenic to $18 \mathrm{~S}$ rDNA in terminal position. In this process, a small segment would have been lost by a fission following the paracentric inversion, corresponding to the additional chromosome (Fig. 4c). Although $18 \mathrm{~S}$ rDNA sites have already been observed on B chromosomes (Polleto et al., 2010), the B chromosome observed in $C$. callichthys does not have ribosomal cistrons, which was verified through silver nitrate impregnation and confirmed through $18 \mathrm{~S}$ rDNA-FISH.

The ill-defined acrocentric B chromosome is completely heterochromatic (Fig. 5). It is possible that the ribosomal cistrons were eliminated, as seen by Jamilena et al. (1994) in Crepis capillaris. This suggests the presence of cell mechanisms which cause a fast heterochromatinization of extra elements, constituting the basis for differentiation of $\mathrm{B}$ chromosomes that isolates them from the rest of the genome (Camacho et al., 2000) or just keeps the gene dosage (Amos \& Dover, 1981). This segment possibly had its gene organization modified through rearranges like proposed by Jamilena et al. (1994). The presence of this B chromosome in all observed cells suggests that a neo-centromere might have been originated, capable of anchoring proteins from the kinetochore like observed by Depinet et al. (1997), differing from other reports of the occurrence of B chromosomes in some populations of $C$. callichthys that presented intra-individual variation (Oliveira et al., 1993; Sanchez \& Fenocchio, 1996), apart from a report of a $\mathrm{B}$ chromosome present in all cells of one individual (Shimabukuro-Dias et al., 2005).

On the present study, the presence of intercalary heterochromatin on the NORs might have facilitated the dispersion and origin of the $\mathrm{B}$ chromosome. The presence of specific repetitive DNAs in B chromosomes has been described for many fish species (Mestriner et al., 2000; Jesus et al., 2003). However, the composition of the ill-defined acrocentric B chromosome was not similar to its origin (GCrich) (Fig. 3c), suggesting different evolutionary mechanisms for B chromosomes (Camacho et al., 2000).

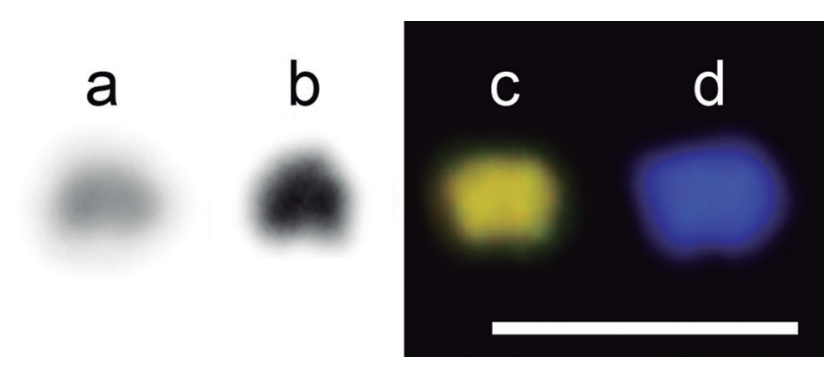

Fig. 5. The ill-defined acrocentric B chromosome: (a) Giemsa stained; (b) C-banded; stained by (c) $\mathrm{CMA}_{3}$ and by (d) DAPI. The bar represents $5 \mu \mathrm{m}$. 
Terminal NORs were described in many populations of C. callichthys (Oliveira et al., 1993; Sanchez \& Fenocchio, 1996; Shimabukuro-Dias et al., 2005). On the present study, the analyzed population shows the same pattern, except for two individuals. These individuals showed the presence of a third NOR bearing chromosome, similar to a situation described for one individual by Porto \& Feldberg (1993). The presence of an additional chromosome bearing NORs is a recurring condition for $C$. callichthys. It is possible that these regions have undergone homogenization like the model proposed by Schweizer \& Loidl (1987); however, this issue demands further studies. Further studies performing in situ hybridization with probes obtained from the ill-defined acrocentric B chromosome are necessary to confirm the proposed hypothesis for the origin of this chromosome in C. callichthys.

\section{Acknowledgments}

The authors are grateful to Instituto Chico Mendes de Conservação da Biodiversidade (ICMBio) for authorizing the capture of the fishes (SISBIO 10522-1). The authors thank to Unioeste for logistical support. This study was financed by Fundação Araucária (Fundação Araucária de Apoio ao Desenvolvimento Científico e Tecnológico do Estado do Paraná), CAPES (Coordenadoria de Aperfeiçoamento de Ensino Superior) and CNPq (Conselho Nacional de Desenvolvimento Científico e Tecnológico).

\section{Literature Cited}

Alves, A. L., F. Porto-Foresti, C. Oliveira \& F. Foresti. 2008. Supernumerary chromosomes in the pufferfish Sphoeroides spengleri - First occurrence in marine Teleostean Tetraodontiformes fish. Genetics and Molecular Biology, 31 (suppl): 243-245.

Amos, A. \& G. Dover. 1981. The distribution of repetitive DNAs between regular and supernumerary chromosomes in species of Glossina (Tsetse): a two-step process in the origin of supernumeraries. Chromosoma, 81: 673-690.

Bertollo, 1. a. c., C. S. Takahashi \& O. Moreira-Filho. 1978. Cytotaxonomic considerations on Hoplias lacerdae (Pisces, Erythrinidae). Brazilian Journal of Genetics, 1: 103-120.

Blanco, D. R., M. R. Vicari, R. F. Artoni, J. B. Traldi \& O. MoreiraFilho. 2012. Chromosomal characterization of armored catfish Harttia longipinna (Siluriformes, Loricariidae): First report of B chromosomes in the genus. Zoological Science, 29: 604-609.

Camacho, J. P., T. F. \& L. W. Beukeboom. 2000. B-chromosome evolution. Philosophical Transactions of the Royal Society of London, 355: 163-178.

Depinet, T. W., J. L. Zackowski, W. L. Earnshaw, S. Kaffe, G. S. Sekhon, R. Stallard, B. A. Sullivan, G. H. Vance, D. L. Van Dyke, H. F. Willard, A. R. Zinn \& S. Schwartz. 1997. Characterization of Neo-Centromeres in Marker Chromosomes Lacking Detectable Alpha-satellite DNA. Human Molecular Genetics, 6: 1195-1204.

Foresti, F., C. Oliveira \& L. F. Almeida-Toledo. 1993. A method for chromosome preparations from large specimens of fishes using in vitro short treatment with colchicines. Experientia, 49: 810-813.

Froese, R. \& D. Pauly. (Eds.). 2013. Fishbase. World Wide Web electronic publication. Available from: http://www.fishbase.org/ search.php (July 2013).

Green, D. M. 2004. Structure and evolution of B chromosomes in amphibians. Cytogenetics and Genome Research, 106: 235-242.

Griffiths, S. P. 2000. The use of clove oil as an anaesthetic and method for sampling intertidal rockpool fishes. Journal of Fish Biology, 57: 1453-1464.

Hatanaka, T. \& P. M. Galetti Jr. 2004. Mapping of the 18 S and 5S ribosomal RNA genes in the fish Prochilodus argenteus Agassiz, 1829 (Characiformes, Prochilodontidae). Genetica, 122: 239-244.

Howell, W. M. \& D. A. Black. 1980. Controlled silver-staining of nucleolus organizer regions with a protective colloidal developer: A 1-step method. Experientia, 36: 1014-1015.

Jamilena, M., C. Ruiz Rejón \& M. R. Rejón. 1994. A molecular analysis of the origin of the Crepis capillaris B chromosome. Journal of Cell Science, 107: 703-708.

Jesus, C. M., P. M. Galetti Jr., S. R. Valentini \& O. Moreira-Filho. 2003. Molecular characterization and chromosomal localization of two families of satellite DNA in Prochilodus lineatus (Pisces, Prochilodontidae), a species with B chromosomes. Genetica, 118: 25-32.

Jones, R. N. \& A. Houben. 2003. B chromosomes in plants: escapees from the A chromosome genome? Trends in Plant Science, 8: 417-423.

Levan, A., K. Fredga \& A. A. Sandberg. 1964. Nomenclature for centromeric position on chromosomes. Hereditas, 52: 201-220.

Margarido, V. P. \& O. Moreira-Filho. 2008. Karyotypic differentiation through chromosome fusion and number reduction in Imparfinis hollandi (Ostariophysi, Heptapteridae). Genetics and Molecular Biology, 31: 235-238.

Martins, C. \& P. M. Galetti Jr. 1999. Chromosomal localization of 5S rDNA genes in Leporinus fish (Anostominae, Characiformes). Chromosome Research, 7: 363-367.

Mendes, V. P., A. L. B. Portela-Castro \& H. F. Júlio-Junior. 2012. First record of supernumerary (B) chromosomes in electric fish (Gymnotiformes) and the karyotype structure of three species of the same order from the upper Parana River basin. Comparative Cytogenetics, 6: 1-16.

Mestriner, C. A., P. M. Galetti Jr, S. R. Valentini, I. R. G. Ruiz, L. D. S. Abel, O. Moreira-Filho \& J. P. M. Camacho. 2000. Structural and functional evidence that a B chromosome in the characid fish Astyanax scabripinnis is an isochromosome. Heredity, 85: 1-9.

Mião, V. P., S. F. Covert \& H. D. VanEtten. 1991. A fungal gene for antibiotic resistance on a dispensable ("B") chromosome. Science, 20: 1773-1776.

Mizoguchi, S. M. H. N. \& I. C. Martins-Santos. 1997. Macro- and microchromosomes B in females of Astyanax scabripinnis (Pisces, Characidae). Hereditas, 127: 249-253.

Néo, D. M., O. Moreira Filho \& J. P. M. Camacho. 2000. Altitudinal variation for B chromosome frequency in the characid fish Astyanax scabripinnis. Heredity, 85: 136-141.

Oliveira, C., L. F. Almeida-Toledo, A. S. Toledo \& F. Foresti. 1988. Supernumerary chromosomes, robertsonian rearrangement and multiple NORs in Corydoras aeneus (Pisces, Siluriformes, Callichthyidae). Caryologia, 41: 227-236.

Oliveira, C., L. F. Almeida-Toledo, L. Mori \& S. A. Toledo-Filho. 1993. Cytogenetic and DNA content in six genera of the family Callichthyidae (Pisces, Siluriformes). Caryologia, 46: 171-188. Oliveira, C., F. Foresti \& A. W. S. Hilsdorf. 2009. Genetics of 
neotropical fish: from chromosomes to populations. Fish Physiology and Biochemistry, 35: 81-100.

Pigozzi, M. I. \& A. J. Solari. 1998. Germ cell restriction and regular transmission of an accessory chromosome that mimics a sex body in the zebra finch, Taeniopygia guttata Chromosome Research, 6: 105-113.

Pinkel, D., T. Straume \& J. W.Gray. 1986. Cytogenetic analysis using quantitative, high-sensitivity, fluorescence hybridization. Proceedings of the National Academy of Sciences USA, 83: 2934-2938.

Plowman, A. B. \& S. M. Bougourd. 1994. Selectively advantageous effects of B chromosomes on germination behaviour in Allium schoenoprasum L. Heredity, 72: 587-593.

Poletto, A. B., I. A. Ferreira \& C. Martins. 2010. The B chromosomes of the African cichlid fish Haplochromis obliquidens harbour $18 \mathrm{~S}$ rRNA gene copies. BMC Genetics, 11: 1-8.

Porto, J. I. R. \& E. Feldberg. 1993. Is Callichthys Linné (Ostariophysi, Siluriformes, Callichthyidae) a monotypic genus? Acta Amazonica, 24: 311-314.

Rejón, M. R., C. R. Rejón \& J. L. Oliver. 1987. Evolución de los cromosomas B. Investigación y Ciencia, 133: 92-101.

Roncati, H. A., M. C. Pastori \& A. S. Fenocchio. 2007. Cytogenetic studies and evolutive considerations on fishes of the family Cichlidae (Perciformes) from Parana River (Argentina). Cytologia, 72: 379-384.

Sanchez, S. \& A. S. Fenocchio. 1996. Karyotypic studies and cytotaxonomic considerations on Callichthys callichthys (Pisces, Siluroidei) from Argentina. Cytologia, 61: 247-252.

Schweizer, D. 1980. Simultaneous fluorescent staining of R bands and specific heterochromatic regions (DA-DAPI bands) in human chromosomes. Cytogenetics and Cell Genetics, 27: 190-193.
Schweizer, D. \& J. Loidl. 1987. A model for heterochromatin dispersion and the evolution of C-band patterns. Chromosomes Today, 9: 61-74.

Sharbel, T. F., D. M. Green \& A. Houben. 1998. B-chromosome origin in the endemic New Zealand frog Leiopelma hochtetteri through sex chromosome devolution. Genome, 41: 14-22.

Shimabukuro-Dias, C. K., C. Oliveira \& F. Foresti. 2005. Comparative cytogenetic studies in species of the subfamily Callichthyinae (Teleostei, Siluriformes, Callichthyidae). Caryologia, 58: 102-111.

Sumner, A. T. 1972. A simple technique for demonstrating centromeric heterocromatin. Experimental Cell Research, 75: 304-306.

Thomas, J. H. 1995. Genomic imprinting proposed as a surveillance mechanism for chromosome loss. Proceedings of the National Academy of Sciences USA, 92: 5737-5741.

Voltolin, T. A., A. Laudicina, J. A. Senhorini, J. Bortolozzi, C. Oliveira, F. Foresti \& F. Porto-Foresti F. 2010. Origin and molecular organization of supernumerary chromosomes of Prochilodus lineatus (Characiformes, Prochilodontidae) obtained by DNA probes. Genetica, 138: 1133-1139.

Submitted August 1, 2013

Accepted February 6, 2014 by Alexandre Hilsdorf

Published September 30, 2014 